\title{
Impact of Climate Change on Epidemiology of Various Pests of Wheat Crop in Punjab Pakistan
}

\author{
Israr Arshad1, Amer Rasul1, Syed Ismat Hussain1, Hafiz Muhammad Usman Aslam ${ }^{2,3}$, \\ Khizar Hayat ${ }^{*}$, Malik Najam Ul Hassan ${ }^{1}$, Sidra Muqeet ${ }^{1 *}$, Amina ${ }^{4}$, Yasir Umar1, \\ Shabab Nasir ${ }^{5}$, Anum Tehseen 6 \\ ${ }^{1}$ Directorate of Pest Warning \& Quality Control of Pesticides, Punjab, Pakistan \\ ${ }^{2}$ Department of Plant Pathology, University of Agriculture, Faisalabad, Pakistan \\ ${ }^{3}$ Department of Plant Pathology and Microbiology, Iowa State University, USA \\ ${ }^{4}$ Horticultural Research Institute, Ayub Agricultural Research Institute (AARI), Faisalabad, Pakistan \\ ${ }^{5}$ Department of Zoology, Government College University Faisalabad, Faisalabad, Pakistan \\ ${ }^{6}$ Institute of Agriculture \& Resource Economics, University of Agriculture, Faisalabad, Pakistan \\ Email: *mynameislove75@gmail.com, *sidrarana61@yahoo.com
}

How to cite this paper: Arshad, I., Rasul, A., Hussain, S.I., Aslam, H.M.U., Hayat, K., Ul Hassan, M.N., Muqeet, S., Amina, Umar, Y., Nasir, S. and Tehseen, A. (2019) Impact of Climate Change on Epidemiology of Various Pests of Wheat Crop in Punjab Pakistan. American Journal of Plant Sciences, 10, 236-247. https://doi.org/10.4236/ajps.2019.101018

Received: December 23, 2018

Accepted: January 22, 2019

Published: January 25, 2019

Copyright $\odot 2019$ by author(s) and Scientific Research Publishing Inc. This work is licensed under the Creative Commons Attribution International License (CC BY 4.0).

http://creativecommons.org/licenses/by/4.0/ (c) () Open Access

\begin{abstract}
Wheat [Triticum aestivum L. (Poaceae)] is the staple diet of people in Pakis$\tan$. It is attacked by many types of pests. Therefore the purpose of this study was to assess the impact of climate change on the ecology and epidemiology of various wheat pests in Punjab, Pakistan. Results indicate that maximum weeds hot spots 242 (5.98\%) Phalaris minor, 45 (1.18\%) wild oat and 203 (5.01\%) broad leaf weeds were noted in 2015. Aphid $31(0.86 \%)$ hot spots were recorded in 2016 while maximum army worm $13(0.26 \%)$ hot spots were noted in 2017. Maximum 70 (1.73\%) spots of yellow rust and $85(2.10 \%)$ hot spots of brown rust were observed during 2015 while $84(4.16 \%)$ spots of loose smut were observed during 2017. ANOVA shows that years have no significant difference $(\mathrm{P}>0.05)$ but weeks have significant effect on occurrence of these pest incidences except brown rust. But regression ANOVA was significant $(P \leq 0.05)$ and regression models equations have been developed on the bases of recorded data. Pest incidence was taken as dependent variable $\mathrm{Y}$ and weather factors i.e. minimum temperature as $\mathrm{X}_{1}$, maximum temperature as $\mathrm{X}_{2}$, relative humidity as $\mathrm{X}_{3}$ and rain fall as $\mathrm{X}_{4}$ were taken as independent variables. This study will help in recommendations for moving forward aiming at integration of biology of rust and smut diseases of wheat with changing climate for development of resistant varieties for resilient and durable management of these pathogens.
\end{abstract}

\section{Keywords}

Climate Change, Wheat, Weeds, Insect Pest, Disease Ecology 


\section{Introduction}

Wheat [Triticum aestivum L. (Poaceae)] is a crop of paramount importance and one of the major staple foods of people in Pakistan [1]. More than 30 wheat varieties are grown in Pakistan. About 50 diseases have been reported on wheat crop. Globally, all crop production practices are being highly challenged by biotic and abiotic stresses. Biotic stresses especially weeds, insect pests and diseases cause devastating damage in terms of yield and quality. On average pests cause $20 \%-37 \%$ yield losses worldwide which translating to approximately $70 \$$ billion annually [2]. In agro-ecosystems, herbivore insects are abundant and likely to colonize within same population and disperse from one crop field to another depending on the availability of plant tissues and feeding behavior of insects. Quantitative feeding style of the herbivore insect on specific crop results in significant damage to the crop during the entire life cycle, which is believed specific insect as pest of that particular crop. Single pest may attack multiple crops within single growing season that make crop rotation and pest management more challenged. Wheat producing areas encounter with either sucking and piercing pests or plant tissue feeding pests. Regional pests also observed in wheat growing areas as major damaging-pests worldwide. The breeding strategy against these insects/pests heavily relies on the inheritance of resistance mechanism in the crops under consideration. Climatic conditions and temperature in particular, plays a significant role in population dynamics of the aphids. A warmer temperature can potentially accelerate the aphid's growth both in terms of number and size, yet, the extreme temperatures can possibly limit the survival and spread of the aphids. Yellow rust (Puccinia striiformis), brown rust (Puccinia recondita) and loose smut (Ustilago tritici) are the most frequently occurring diseases of wheat crop across the wheat cultivating areas in Pakistan which greatly affect the production of wheat and may lead to significant yield losses every year [3] [4] [5]. Although, many diseases of wheat are considered of little values but severe attack of black/stem rust was recorded on wheat crop in 1906-08 at Mirpurkhas, Sindh, Pakistan. Long ago, yellow/stripe and brown/leaf rust were also seen in 1978 all over the wheat producing areas of Pakistan [6]. Yellow stripe rust, caused by a fungus Puccinia striiformis tritici, is one of the devastating diseases of wheat in all wheat growing areas of the World [7]. The severity and frequency of yellow stripe rust epidemics have increased rapidly since 2000 [8]. The prevailing climatic predictions indicate that weather conditions like mild atmospheric temperature is becoming more favorable for rusts than previously occurring and leading to more frequent destructive epidemics of medium to high intensity in longer term [9]. Historically wheat stem rust (Puccinia graminis tritici) has been considered economically more dangerous disease of wheat but the increased geographic extent and yield losses caused by stripe rust indicate that stripe rust is more overwhelming worldwide [10] [11]. Climate change may affect agricultural system in a variety of ways by changing in pests and diseases incidences and intensities in addition to many other abnormalities which may 
damage foods for their nutritional quality [12]. Although, it is limited but the studies showed that climate change may change the developmental phases of pathogens affecting the crops. The climate change may disturb the pathogens dispersal, which can shift the geographical distribution of hosts and pathogens, resulting in more crop losses [13]. Although, novel pathogens originally occur in limited geographic areas, they can quickly emerge in new regions if they find a production system with vulnerable hosts and favorable environmental conditions. Many pathogens have been introduced long ago in widespread food crops and are now widely distributed geographically [14]. Though the introductions may have occurred centuries ago, the development of such ubiquitous pathogens remains an important cause of concern over the risk of recurrence caused by the adventitious spread of new multi-virulence breeds [15] or new highly aggressive strains [16]. A deep understanding of the origin, distribution and diversity of inoculums reservoirs and past and new pathways of migration of these pathogens is critical to understand current epidemics, developing risk assessment models and mitigating the potential adverse effects of disease [17] [18]. This is especially true for pathogens capable of long-distance migration, where any newly beneficial mutant (increased virulence, aggressiveness or resistance to fungal surfactants) can spread across large geographical areas [19]. Now, brown and yellow rust is a prime example of a worldwide pathogen [20] that has significant negative effects on wheat production due to emergence and invasion of new breeds [10] [16] [21] [22] [23]. Despite the ability to migrate long-haul, yellow rust's worldwide expansion is relatively new, with most emerging site emergencies only reported in the last two decades [9]. Therefore, the purpose of this study was to assess the impact of climate change on the ecology and epidemiology of rust smut and other wheat diseases in Pakistan. This will be followed by recommendations for moving forward aiming at integration of biology of different pests of wheat under changing climate for development of resistant varieties for resilient and durable management of these pest complexes.

\section{Materials and Methods}

Surveys of central mix crop zone of Punjab (Pakistan), including four districts viz. Faisalabad, TT Singh, Jhang and Chiniot (Figure 1) were conducted in 2015, 2016 and 2017 to determine the pest incidences of wheat crop. Pest scouting for narrow and broad leaf weeds was done by Quadrate method by placing $\mathrm{I}^{2} \mathrm{qu}-$ adrate at four places randomly and counting the weeds population in the field. Hot spot of $P$. minor and wild oat was 2 weeds per $\mathrm{I}^{2}$ each. While aphid and army worm population was noted by selecting 20 tillers randomly and counting the insect's population on upper, middle and lower leaf in sequence. Hot spot of aphid was 15 aphids/spike, while army worm on appearance. Diseases incidence was recorded as described by [3]. For rust and smut scale 0 - 9 was used [24]. Hot spots of diseases were also considered just on appearance. Surveys were conducted randomly in farmers' fields at Tehsil level by pest scouting eight to 


\section{Study Area (Faisalabad Div.)}
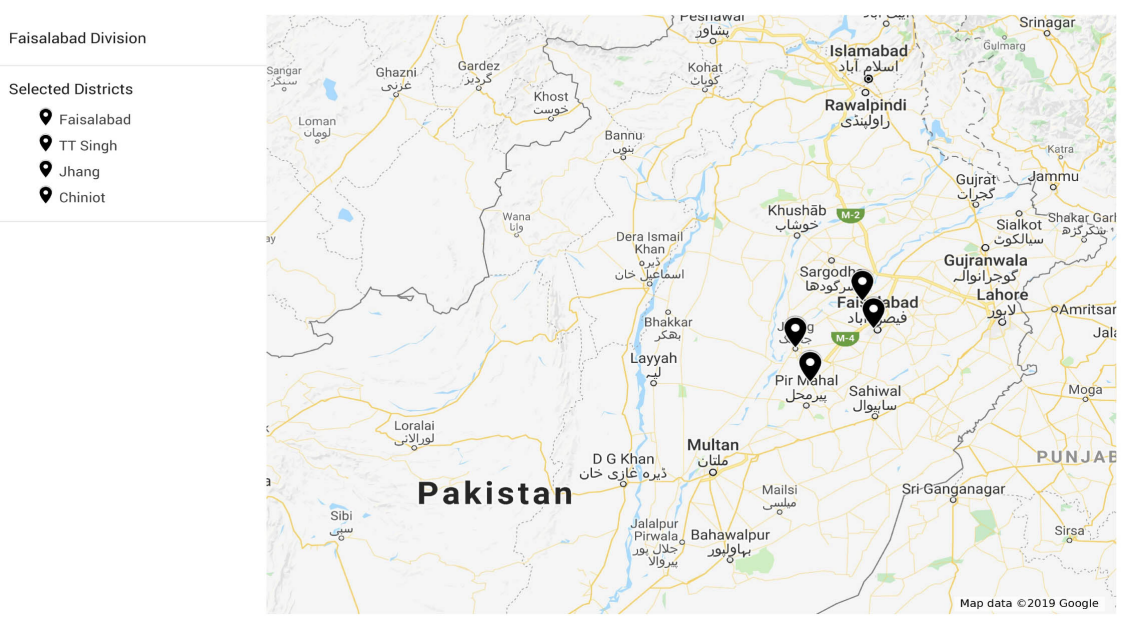

Figure 1. Study area.

ten spots daily, 4 days a week from $1^{\text {st }}$ January to $15^{\text {th }}$ of April of each three years 2015-17. For accurate identification, infected wheat samples were brought to Plant Pathological Research Institute PPRI located in Ayyub Agricultural Research Institute (AARI), Faisalabad.

\section{Statistical Analysis}

Factorial ANOVA without replication was performed to evaluate the differences among different pest incidences and multiple regression ANOVA were also calculated to correlate various pests incidence with climatic conditions at $5 \%$ significance levels using SPSS Ver.15.

\section{Results}

Total 4046, 3603 and 4892 spots were checked during 2015, 2016 and 2017 respectively. Results indicate that maximum weeds hot spots 242 (5.98\%) Phalaris minor, 45 (1.18\%) wild oat and 203 (5.01\%) broad leaf weeds were noted in 2015 (Figure 2). Aphid $31(0.86 \%)$ hot spots were recorded in 2016 while maximum army worm 13 (0.26\%) hot spots were noted in 2017 [5]. Week wise hot spots of p. minor, wild oat and broad leaf weeds are shown in Figures 3-5 respectively. Figure 6 shows total spots and\% age hot spots of wheat aphid and army worm. Week wise hot spots of aphid and army worm are shown in Figure 7 and Figure 8 respectively. Whereas $1.12 \%-1.73 \%$ yellow rust, $1.39 \%-2.10 \%$ brown rust and $2.83 \%-4.16 \%$ L. smut in three years are shown in Figure 9.

While yellow rust, brown rust and loose smut are shown in Figures 10-12 respectively. Results indicate that maximum $p$. minor spots were recorded in $3^{\text {rd }}$ week of Jan 2015, whereas w.oat appeared at peak on 4th week of January 2015. Broad leaf weeds reached their climax on $3^{\text {rd }}$ week of January 2017. Aphid hot spot were noted maximum on $1^{\text {st }}$ and $2^{\text {nd }}$ week of March. Army worm appear on $1^{\text {st }}$ week of February 2017. Maximum spots of yellow rust and loose smut were 


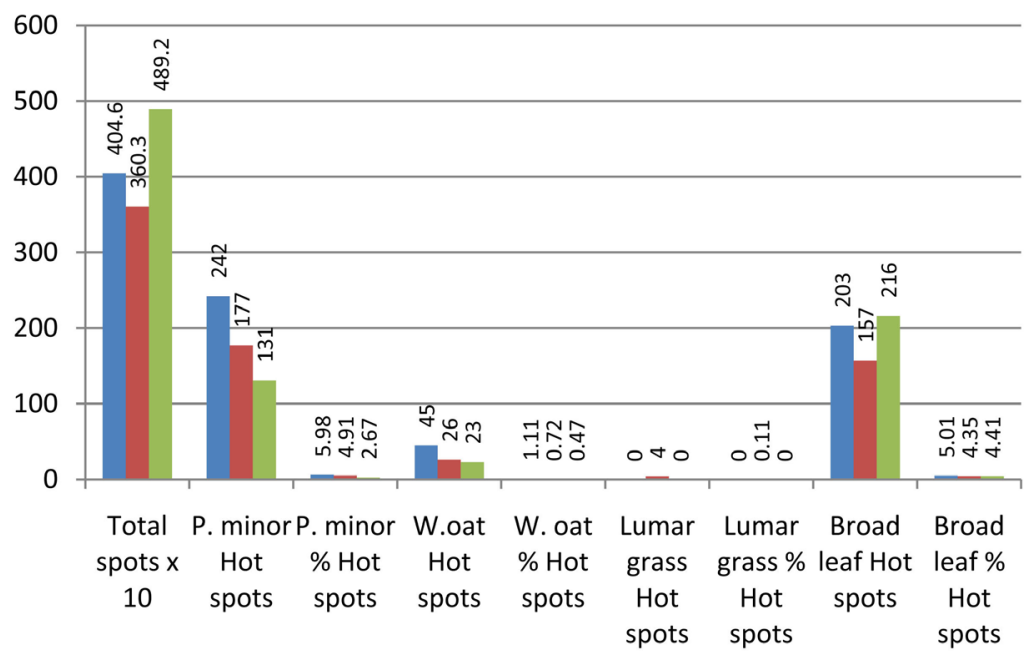

Figure 2. Total spots and\% age hot spots of different weeds.

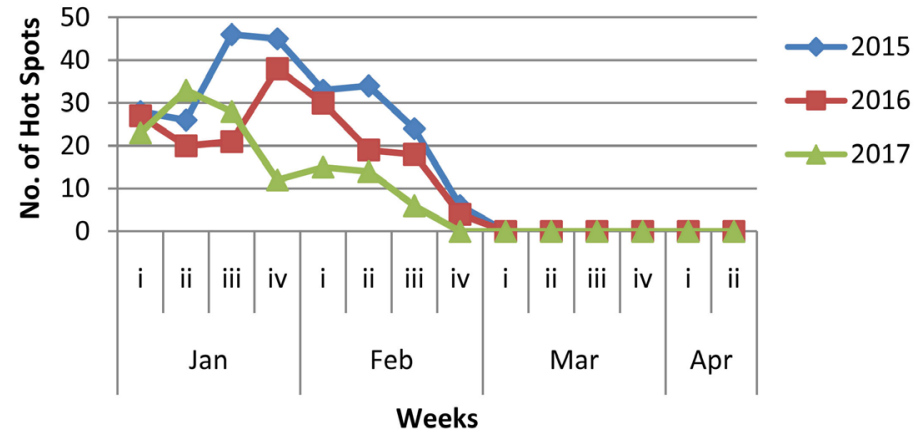

Figure 3. Week wise hot spots of $p$. minor.

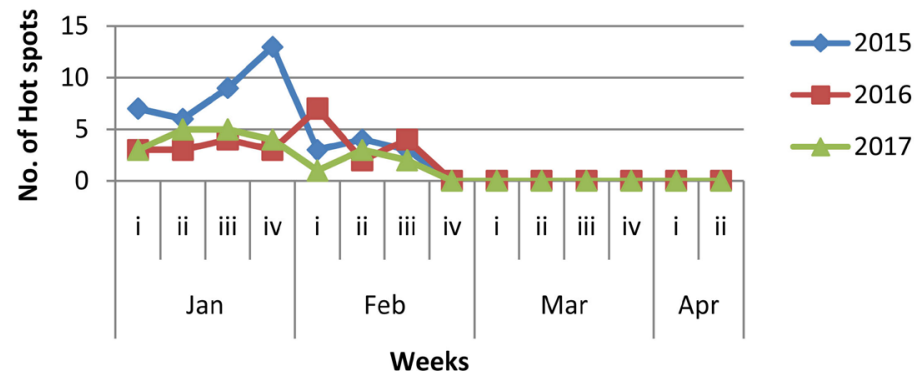

Figure 4. Week wise hot spots of wild oat.

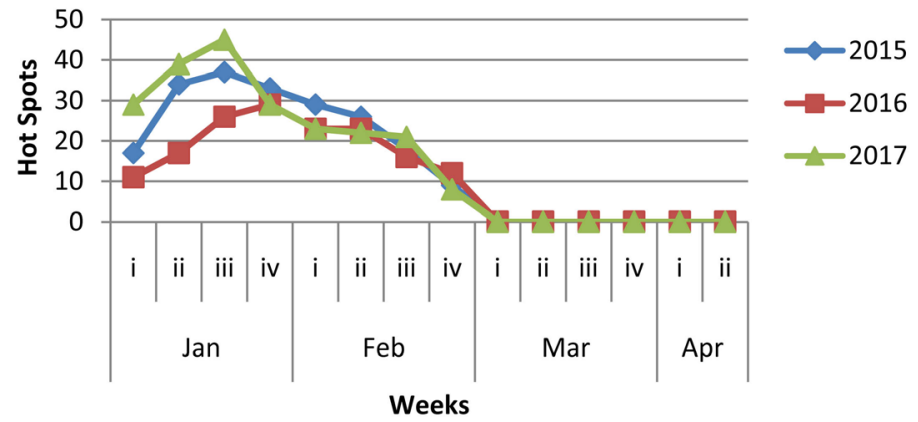

Figure 5. Week hot spots of broad leaf weeds. 


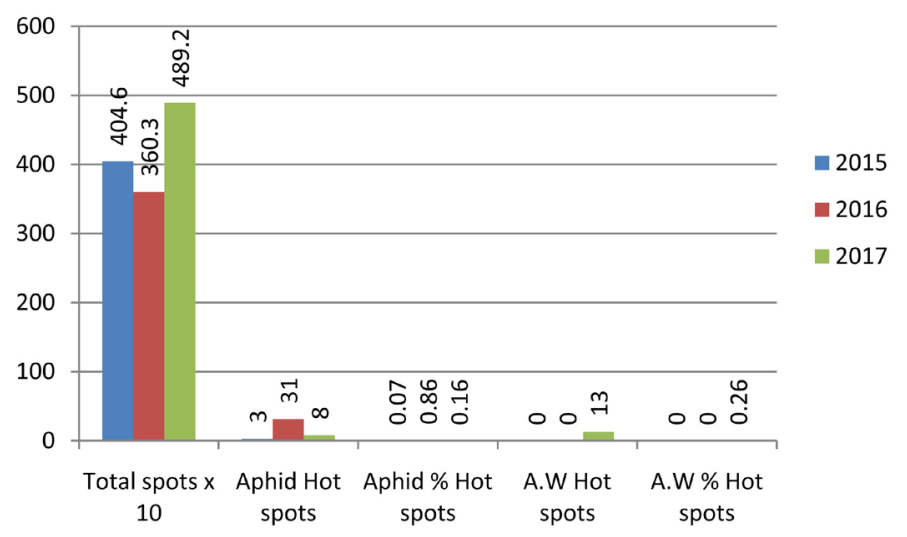

Figure 6. Total spots and \% age hot spots of wheat aphid and army worm.

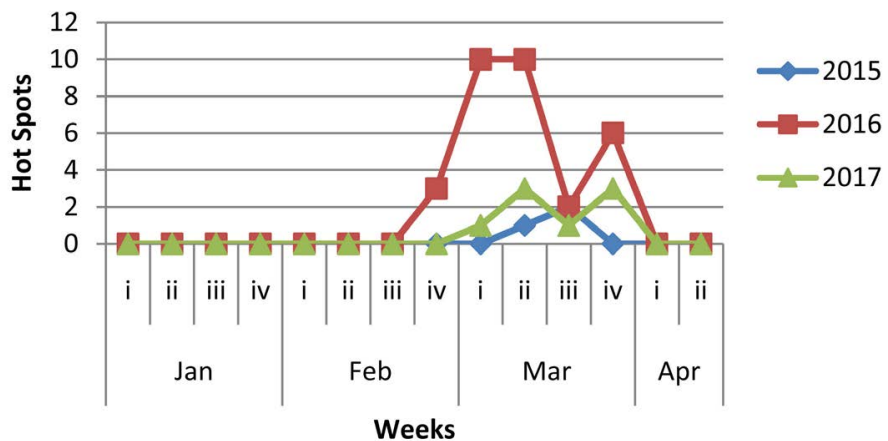

Figure 7. Week wise hot spots of aphid.

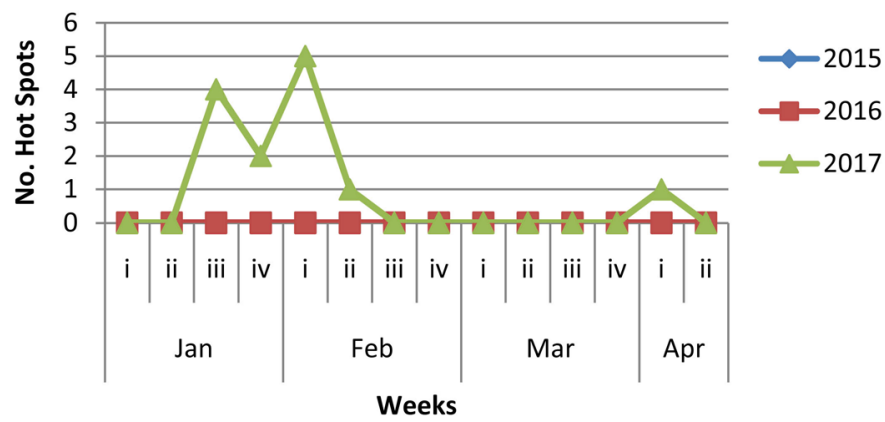

Figure 8. Week wise hot spots of army worm.

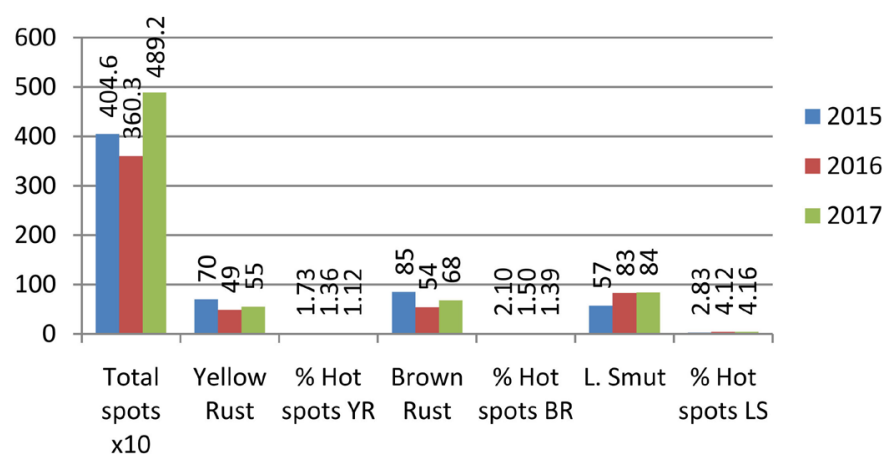

Figure 9. Total spots, total hot spots and\% age hot spots of $\mathrm{YR}=$ Yellow rust, $\mathrm{BR}=$ Brown rust and LS $=$ Loose smut. 


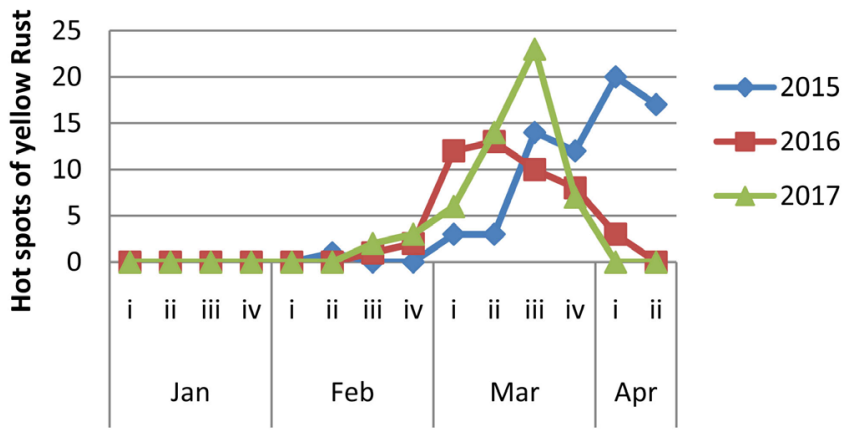

Figure 10. Week wise hot spots of yellow rust.

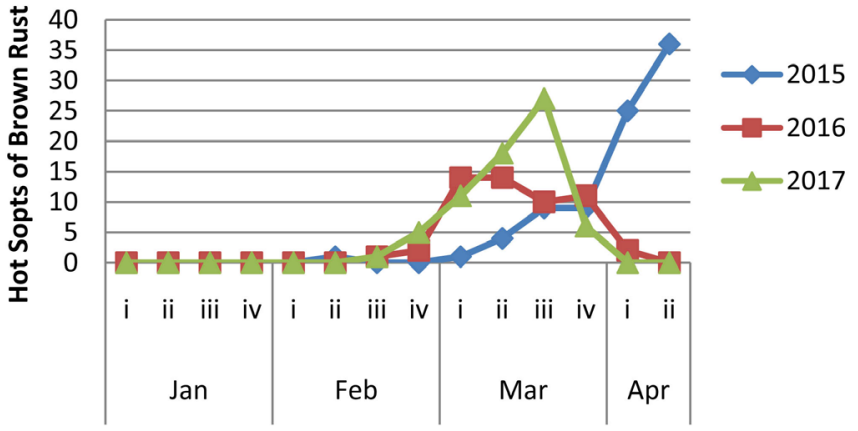

Figure 11. Week wise hot spots of brown rust.

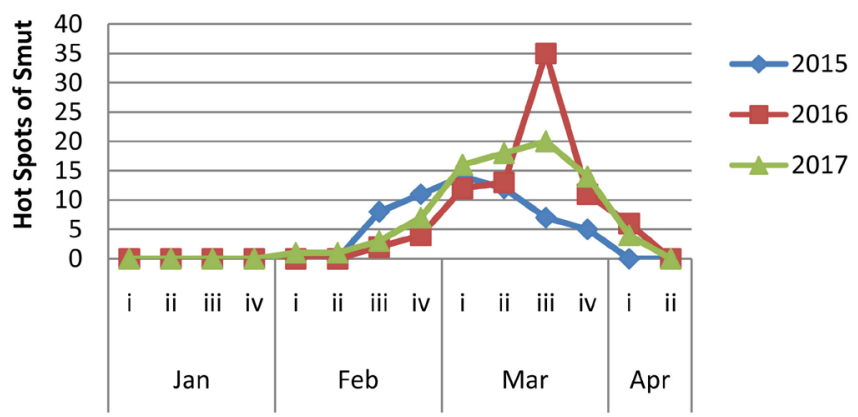

Figure 12. Week wise hot spots of loose smut.

recorded in $3^{\text {rd }}$ week of March while brown rust appeared on $2^{\text {nd }}$ week of April from 2015-17.

While ANOVA for weeds, insect pests and diseases are shown in Tables 1-3 respectively. ANOVA shows that year have no significant difference $(\mathrm{P}>0.05)$ but week have significant effect on occurrence of pest and disease incidence except brown rust. But regression ANOVA was significant $(\mathrm{P} \leq 0.05)$ and regression equations are given in Table 4. Pest incidence was taken as $\mathrm{Y}$ and weather factors i.e. Minimum temperature as $X_{1}$ maximum temperature as $X_{2}$ relative humidity as $X_{3}$ and rain fall as $X_{4}$. Multiple regression equation were derived using SPSS Ver.15.

Results indicate that maximum 70 (1.73\%) spots of yellow rust and $85(2.10 \%)$ hot spots of brown rust were observed during 2015 while $84(4.16 \%)$ of loose smut were observed during 2017. 
Table 1. ANOVA for $P$. minor.

\begin{tabular}{lccccccc}
\hline & Source of Variation & SS & df & MS & F & P-value & F crit \\
\hline P. minor & Years & 444.333 & 2 & 222.167 & 4.891 & 0.016 & 3.369 \\
& Weeks & 7248.286 & 13 & 557.560 & 12.275 & 0.000 & 2.119 \\
& Error & 1181.000 & 26 & 45.423 & & & \\
& Total & 8873.619 & 41 & & & & \\
\hline \multirow{2}{*}{ Wild oat } & Years & 20.333 & 2 & 10.167 & 2.863 & 0.075 & 3.369 \\
& Weeks & 246.952 & 13 & 18.996 & 5.349 & 0.000 & 2.119 \\
& Error & 92.333 & 26 & 3.551 & & & \\
& Total & 359.619 & 41 & & & & \\
\hline \multirow{2}{*}{ Broad leaf } & Years & 137.2857 & 2 & 68.643 & 3.284 & 0.053 & 3.369 \\
& Weeks & 7375.905 & 13 & 567.377 & 27.148 & 0.000 & 2.119 \\
& Error & 543.381 & 26 & 20.899 & & & \\
& Total & 8056.571 & 41 & & & & \\
\hline
\end{tabular}

Table 2. ANOVA for aphid and army worm.

\begin{tabular}{cccccccc}
\hline & Source of Variation & SS & df & MS & F & P-value & F crit \\
\hline \multirow{2}{*}{ Aphid } & Years & 31.857 & 2 & 15.929 & 4.220 & 0.026 & 3.369 \\
& Weeks & 102.000 & 13 & 7.846 & 2.079 & 0.054 & 2.119 \\
& Error & 98.143 & 26 & 3.775 & & & \\
\hline \multirow{2}{*}{ Army worm } & Total & 232.000 & 41 & & & & \\
& Years & 8.048 & 2 & 4.024 & 4.493 & 0.021 & 3.369 \\
& Weeks & 11.643 & 13 & 0.896 & 1.000 & 0.479 & 2.119 \\
& Error & 23.286 & 26 & 0.896 & & & \\
& Total & 42.976 & 41 & & & & \\
\hline
\end{tabular}

Table 3. ANOVA for diseases.

\begin{tabular}{cccccccc}
\hline & Source of Variation & SS & df & MS & F & P-value & F crit \\
\hline Yellow rust & Years & 16.714 & 2.000 & 8.357 & 0.342 & 0.713 & 3.369 \\
& Weeks & 989.810 & 13.000 & 76.139 & 3.119 & 0.007 & 2.119 \\
& Error & 634.619 & 26.000 & 24.408 & & & \\
\hline \multirow{2}{*}{ Brown rust } & Total & 1641.143 & 41.000 & & & & \\
& Years & 34.429 & 2.000 & 17.214 & 0.272 & 0.764 & 3.369 \\
& Weeks & 1260.786 & 13.000 & 96.984 & 1.534 & 0.171 & 2.119 \\
& Error & 1643.571 & 26.000 & 63.214 & & & \\
& Total & 2938.786 & 41.000 & & & & \\
\hline \multirow{2}{*}{ Loose smut } & Years & 33.476 & 2.000 & 16.738 & 0.879 & 0.427 & 3.369 \\
& Weeks & 1842.667 & 13.000 & 141.744 & 7.442 & 0.000 & 2.119 \\
& Error & 495.190 & 26.000 & 19.046 & & & \\
& Total & 2371.333 & 41.000 & & & & \\
\hline
\end{tabular}


Table 4. Regression models.

$$
\begin{gathered}
Y_{1}=54.966-0.949 X_{1}-0.903 X_{2}-0.086 X_{3}-0.363 X_{4} \\
Y_{2}=11.928-0.224 X_{1}-0.128 X_{2}-0.033 X_{3}-0.068 X_{4} \\
Y_{3}=67.684-1.333 X_{1}-0.620 X_{2}-0.168 X_{3}-0.430 X_{4} \\
Y_{4}=-9.412+0.164 X_{1}+0.015 X_{2}+0.086 X_{3}+0.056 X_{4} \\
Y_{5}=2.692-0.035 X_{1}-0.029 X_{2}-0.017 X_{3}-0.002 X_{4} \\
Y_{6}=34.381+0.695 X_{1}+0.289 X_{2}+0.262 X_{3}+0.146 X_{4} \\
Y_{7}=37.898+0.799 X_{1}+0.376 X_{2}+0.276 X_{3}+0.128 X_{4} \\
Y_{8}=1.152+0.225 X_{1}+0.116 X_{2}-0.079 X_{3}+0.437 X_{4}
\end{gathered}
$$

$Y_{1}=$ Hot spots of $p$. minor,$Y_{2}=$ Hot spots of wild oat; $Y_{3}=$ Hot spots of broad leaf; $Y_{4}=$ Hot spots of aphid; $Y_{5}=$ Hot spots of Arm $Y$ worm; $Y_{6}=$ Hot spots of Yellow rust; $Y_{7}=$ Hot spots of brown rust; $Y_{8}=$ Hot spots L. Smut.

\section{Discussion}

Extensive surveys have been conducted to collect weeds, insect pests, diseases and weather data. Multiple regression models have been developed first time in Punjab Pakistan. This study will be helpful for future risk assessment of losses associated with various pests of wheat crop. Integrating the data series and reproduction models can be valuable approach in projection of future climate change on population dynamics of wheat pests. This need to collect long term weather parameters data to create and validate associated "Climate Crop Disease Models" [25] [26] [27] [28].

In addition to the recently colonized areas, new races are known to emerge periodically through the acquisition of new virulence. The population structure of Yellow rust is therefore likely to be characterized by a complex mixture of reappearances of different genotypes to continuous wheat acreage and rare soil events due to long-distance migration. The recent spread of the pathogen is likely to lead to significant changes in the patterns of population differentiation between geographic regions and possibly erase the signature of previous colonization events.

A recent global population diversity analysis of yellow rust found a strong demographic breakdown within yellow rust, with isolates grouped by geographical origin despite long-haul migration capacity [20] [23]. This pattern is in contrast to the earlier understanding of rust's global population structure, which considers the potential replacement locally populations from new invasions [19] [22]. Based on survey data monitoring the emergence of strains with newly acquired virulence defeating the recently used Yr (resistance) genes, the population structure of yellow rust has been considered to be due to a continuous replacement of already existing populations by the newly formed races. This process is known as the boom and bust cycle [29]. Such geographic migrations have recently been documented in a global population analysis of yellow rust 
[20], but recently scattered genotypes appear to coincide with older populations specific to the main geographical areas, suggesting that migrants displace the local population despite the Capacity not replace recurring remote dispersion. In contrast, invasion of a region by new genotypes in colonial populations would result in a population replacing the original population.

This has been observed in the US, where the yellow rust population after 2000 is dominated by aggressive breeds such as yellow rust $\mathrm{S} 1$ or its derivatives originating in the East Africa or Middle East region [30].

\section{Conclusion}

Weeds insect pest and diseases are highly affected by weather factors. Therefore studies must be conducted to explore additional factors like crop genotype and soil structure to monitor the occurrence of wheat pests in developing countries like Pakistan.

\section{Acknowledgements}

The authors are highly grateful to department of Pest Warning \& Quality Control of Pesticides, Punjab, Pakistan for providing competent staff to collect the field data.

\section{Conflicts of Interest}

The authors declare no conflicts of interest regarding the publication of this paper.

\section{References}

[1] Rattu, A.R., Shahzad, A., Muhammad, F., Muhammad, Z., Shamim, I. and Yasmin, A. (2011) Status of Foliar Diseases of Wheat in Punjab, Pakistan. Mycopath, 9, $39-42$.

[2] Pimentel, D., Houser, J., Preiss, E., White, O., Fang, H., Mesnick, L., Barsky, T., Tariche, S., Schreck, J. and Alpert, S. (1997) Water Resources Agriculture, the Environment and Society. BioScience, 47, 97-106. https://doi.org/10.2307/1313020

[3] Iftikhar, S., Asad, S., Anjum, M., Iftikhar, I. and Amir, S. (2006) Prevalence and Distribution of Foliar Blights Pathogens of Wheat in Different Agro-Ecological Zones of Pakistan with Special Reference to Bipolaris sorokiniana. Pakistan Journal of Botany, 38, 205-210.

[4] Asad, S., Sultan, A., Iftikhar, S., Munir, A., Ahmad, I. and Ayub, N. (2007) Pathogenic Diversity in Bipolaris sorokiniana Isolates Collected from Different Wheat Growing Areas of the Punjab and NWFP of Pakistan. Pakistan Journal of Botany, 39, 2225-2231.

[5] Iftikhar, S., Asad, S. and Anjum, M. (2010) Incidence of Bipolaris sorokiniana in Punjab and Khyber Pakhtoon Khawa, Pakistan. Pakistan Journal Phytopathology, 22, 95-97.

[6] Anonymous (2000) Wheat Rust. CDRI, TARC, Karachi, 75270. (In Urdu)

[7] Chen, W., Wellings, C., Chen, X., Kang, Z. and Liu T. (2014) Wheat Stripe (Yellow) Rust Caused by Puccinia striiformis F. sp.tritici. Molecular Plant Pathology, 15, 
433-446. https://doi.org/10.1111/mpp.12116

[8] Hughes, M. (2016) Cereal Rust Bulletins.

https://www.ars.usda.gov/midwest-area/st-paul-mn/cereal-disease-lab/docs/cereal-r \%20ust-bulletins/cereal-rust-bulletins/

[9] Lyon, B. and Kirk B. (2017) Impact of Climate Change and Race Evolution on the Epidemiology and Ecology of Stripe Rust in Central and Eastern USA and Canada. Canadian Journal of Plant Pathology, 39, 385-392. https://doi.org/10.1080/07060661.2017.1368713

[10] Milus, E.A., Kristensen, K. and Hovmoller, M.S. (2009) Evidence for Increased Aggressiveness in a Recent Widespread Strain of Puccinia striiformis F. sp. tritici Causing Stripe Rust of Wheat. Phytopathology, 99, 89-94. https://doi.org/10.1094/PHYTO-99-1-0089

[11] Wellings, C.R. (2011) Global Status of Stripe Rust, a Review of Historical and Current Threats. Euphytica, 179, 129-141. https://doi.org/10.1007/s10681-011-0360-y

[12] Myers, S.S., Smith, M.R., Guth, S., Golden, C.D., Vaitla, B., Mueller, N.D., Dangour, A.D. and Huybers, P. (2017) Climate Change and Global Food Systems, Potential Impacts on Food Security and under Nutrition. Annual Review of Public Health, 38, 259-277. https://doi.org/10.1146/annurev-publhealth-031816-044356

[13] Coakley, S.M. (1999) Climate Change and Plant Disease Management. Annual Review of Phytopathology, 37, 399-426. https://doi.org/10.1146/annurev.phyto.37.1.399

[14] Palm, M.E. (2001) Systematics and the Impact of Invasive Fungi on Agriculture in the United States. BioScience, 51, 141-147. https://doi.org/10.1641/0006-3568(2001)051[0141:SATIOI]2.0.CO;2

[15] Singh, R.P., Willima, H.M., Huerta-Espino, J., Kinyua, M.G., Wanyera, R., Njau, P. and Ward, R.W. (2006) Current Status, Likely Migration and Strategies to Mitigate the Threat to Wheat Production from Race Ug99 (TTKS) of Stem Rust Pathogen. CAB Reviews, 1, 054. https://doi.org/10.1079/PAVSNNR20061054

[16] Hovmoller, M.S., Yahyaoui, A.H., Milus, E.A. and Justesen, A.F. (2008) Rapid Global Spread of Two Aggressive Strains of a Wheat Rust Fungus. Molecular Ecology, 17, 3818-3826. https://doi.org/10.1111/j.1365-294X.2008.03886.x

[17] Campbell, F.T. (2001) The Science of Risk Assessment for Phytosanitary Regulation and the Impact of Changing Trade Regulations. BioScience, 51, 148-153. https://doi.org/10.1641/0006-3568(2001)051[0148:TSORAF]2.0.CO;2

[18] Perrings, C., Williamson, M., Barbier, E.B., Delfino, D., Dalmazzone, S., Shogren, J., Simmons, P. and Watkinson, A. (2002) Biological Invasion Risks and the Public Good: An Economic Perspective. Conservation Ecology, 6, 1. https://doi.org/10.5751/ES-00396-060101

[19] Brown, J.K.M. and Hovmoller, M.S. (2002) Aerial Dispersal of Pathogens on the Global and Continental Scales and Its Impact on Plant Disease. Science, 297, 537-541. https://doi.org/10.1126/science.1072678

[20] Ali, S., Gladieux, P., Leconte, M., Gautier, A., Justesen, A.F., Hovmoller, M.S., Enjalbert, J., de Vallavieille-Pope, C. and McDonald, B.A. (2014) Origin, Migration Routes and Worldwide Population Genetic Structure of the Wheat Yellow Rust Pathogen Puccinia striiformis F. sp. tritici. PLOS Pathogens, 10, e1003903. https://doi.org/10.1371/journal.ppat.1003903

[21] Wellings, C.R. (2007) Puccinia striiformis in Australia, A Review of the Incursion, Evolution and Adaptation of Stripe Rust in the Period 1979-2006. Australian Journal of Agricultural Research, 58, 567-575. https://doi.org/10.1071/AR07130 
[22] Hovmoller, M.S., Walter, S., Bayles, R.A., Hubbard, A., Flath, K., Sommerfeldt, N., Leconte, M., Czembor, P., Rodriguez-Algaba, J. and Thach, T. (2016) Replacement of the European Wheat Yellow Rust Population by New Races from the Centre of Diversity in the Near-Himalayan Region. Plant Pathology, 65, 402-411. https://doi.org/10.1111/ppa.12433

[23] Ali, S., Rodriguez-Algaba, J., Thach, T., Sørensen, C.K., Hansen, J.G., Lassen, P., Nazari, K., Hodson, D., Justesen, A.F. and Hovmoller, M.S. (2017) Yellow Rust Epidemics Worldwide Were Caused by Pathogen Races from Divergent Genetic Lineages. Frontiers in Plant Science, 8, 1057. https://doi.org/10.3389/fpls.2017.01057

[24] Peterson, R.F., Campbell, A.B. and Hannah, A.E. (1948) A Diagrammatic Scale for Estimating Rust Intensity of Leaves and Stem of Cereals. Canadian Journal of Research, Section A, 26, 496-500. https://doi.org/10.1139/cjr48c-033

[25] Butterworth, M.H., Semenov, M.A., Barnes, A., Moran, D., West, J.S. and Fitt, B.D.L. (2010) North-South Divide, Contrasting Impacts of Climate Change on Crop Yields in Scotland and England. Journal of the Royal Society Interface, 7, 123-130. https://doi.org/10.1098/rsif.2009.0111

[26] Evans, N., Butterworth, M.H., Baierl, A., Semenov, M.A., West, J.S. and Barnes, A. (2010) The Impact of Climate Change on Disease Constraints on Production of Oilseed Rape. Food Security, 2, 143-156. https://doi.org/10.1007/s12571-010-0058-3

[27] Madgwick, J.W., West, J.S., White, R.P., Semenov, M.A., Townsend, J.A. and Turner, J.A. (2011) Impacts of Climate Change on Wheat Anthesis and Fusarium Ear Blight in the UK. European Journal of Plant Pathology, 130, 117-131. https://doi.org/10.1007/s10658-010-9739-1

[28] Richerzhagen, D., Racca, P., Zeuner, T., Kuhn, C., Falke, K. and Kleinhenz, B. (2011) Impact of Climate Change on the Temporal and Regional Occurrence of Cercospora Leaf Spot in Lower Saxony. Journal of Plant Diseases and Protection, 118, 168-177. https://doi.org/10.1007/BF03356400

[29] De Vallavieille-Pope, C., Ali, S., Leconte, M., Enjalbert, J., Delos, M. and Rouzet, J. (2012) Virulence Dynamics and Regional Structuring of Puccinia striiformis F. $s p$. tritici in France between 1984 and 2009. Plant Diseases, 96, 131-140. https://doi.org/10.1094/PDIS-02-11-0078

[30] Walter, S., Ali, S., Kemen, E., Nazari, K., Bahri, B.A., Enjalbert, J., Hansen, J.G., Brown, J.K.M., Sicheritz-Pontén, T. and Jones, J. (2016) Molecular Markers for Tracking the Origin and Worldwide Distribution of Invasive Strains of Puccinia striiformis. Ecology and Evolution, 6, 2790-2804. https://doi.org/10.1002/ece3.2069 